\title{
CRIMINAL ACTIONS PERFORMED BY NOTARY STAFF THAT OPEN CONFIDENTIALITY OF NOTARY POSITION
}

\author{
By \\ Murshal Sanjaya \\ Universitas Pasundan Bandung \\ Email: murshal.sanjaya@unpas.ac.id
}

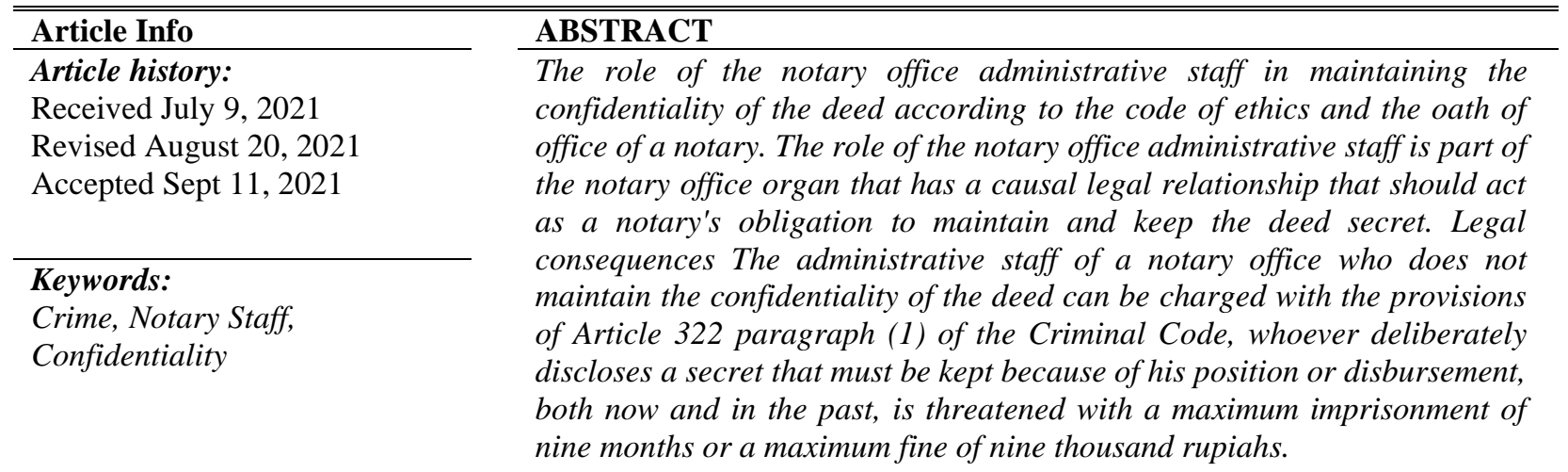

This is an open access article under the CC BY-SA license.

Corresponding Author:

Murshal Sanjaya

Universitas Pasundan Bandung

Email: murshal.sanjaya@unpas.ac.id

\section{INTRODUCTION}

A Notary is required to have high moral values in addition to having knowledge and skills so that he is able to design and make various authentic deeds. authorized to make authentic deeds and other authorities as referred to in this Law. According to the article, it is quite clear that the task of a notary is to make an authentic deed, where the authentic deed is one of the legal products.

Based on the provisions of Article 1 paragraph (1) of Law Number 30 of 2004 concerning the Position of a Notary, which is contained in the State Gazette of the Republic of Indonesia of 2004 number 117 (hereinafter written the Law on Notary Positions / UUJN) states, a notary is a public official authorized to make authentic deeds and other authorities as referred to in this Law. The position of the Notary as a public official, in the sense that the authority that exists in the Notary is never given to other officials, as long as and as long as the authority does not become the authority of other officials in making authentic deeds and other authorities, then the authority becomes the authority of the Notary.

In the formulation of Article 15 of the UUJN it is clearly explained that in carrying out its obligations the notary acts independently, which means that the notary must not be influenced by other interests related to one of the parties, and it is also prohibited to side with one of the parties.

The aspect of certainty is one of the main things that must be considered by a notary in carrying out his position. An authentic deed made by a notary must really reflect the wishes of the parties, because if it is legally signed by the parties, the deed will act as a law that will bind or be obeyed by the parties involved in the deed. Authentic deeds made by or before a Notary are expected to be able to guarantee certainty, order and legal protection.

Therefore, in carrying out his work, it is limited and regulated in the Law on Notary Positions so as not to commit violations that can harm the client or himself. However, as a human being, in carrying out his profession, a Notary cannot be separated from the possibility of committing acts that deviate from the applicable provisions or

Journal homepage: https://bajangjournal.com/index.php/IJSS 
committing acts against the law, let alone being carried out by notary staff who participated in the act. An unlawful act is defined as a civil error committed by a person who causes harm to another person by violating the rights and obligations determined by law for which compensation can be requested for the resulting loss.

An authentic deed is the strongest and binding evidence for the parties in the deed, a deed can produce strong evidence of how the incident occurred and the deed must be trusted and cannot be doubted because in making the deed, the parties are in front of the authorized official to make the deed, then the parties cannot doubt its authenticity. If the parties doubt or dispute the deed, they should be able to first prove the untruth of the authentic deed.

Notary is a public official who is authorized to make an authentic deed and has other authorities as referred to in this law or based on other laws. The authority to make this authentic deed is only exercised by a Notary insofar as the making of a certain authentic deed is not reserved for other public officials.

Provisions regarding the physical, material and formal form of a deed made by a notary are guidelines that must be carried out by a notary in making and issuing a deed.

These limits can be used as a reference to give civil or administrative sanctions to Notaries who violate the procedures stipulated in the UUJN. However, it turns out that the limits specified in the UUJN are often withdrawn and resolved criminally or used as the basis for criminalizing a Notary.

Therefore, criminal law must be responsive to tackling various crimes committed by notary staff by placing them as legal subjects in criminal law that can be accounted for so as to provide a deterrent effect, especially regarding the criminal liability of notary staff in criminal acts.

Not infrequently usually in carrying out their work, to speed up administration and management, Notary workers use methods that violate the law, for example, falsification of letters or documents, both in terms of content and others, such as forging signatures, revealing secrets and so on. This is what does not rule out the possibility of dragging a Notary as an employer, in a problem, in the event that a Notary worker commits a crime.

The notary in making the deed needs to keep all forms of information obtained while carrying out his office, which are regulated in the code of ethics and the notary position law. However, the notary in making the deed generally involves the administrative staff of the notary office.

Based on the description above, the formulation of the problem is:

1. What is the notary's responsibility in relation tonotary staff who disclose the confidentiality of the notary position?

2. What are the legal consequences?a crime committed by a notary staff who discloses the confidentiality of a notary's position?

\section{LITERATURE REVIEW}

1. Notary Public

a. Understanding and Legal Basis for the Existence of a Notary

Notaries are one of the oldest branches of the legal profession in the world. The position of Notary was born because the community needed it, not a position that was deliberately created and then socialized to the public. The history of the birth of a Notary begins with the birth of a professionscribae in ancient Rome (2nd and 3rd centuries $\mathrm{AD})$.

The notary is required to be responsible for the deed he has made, sometimes the deed made before the notary contains false information, fraud and even untruth and is often subject to Articles 263, 264, and 266 in conjunction with Article 55 of the Criminal Code. The task of a notary is to enter data and information provided by the parties, in accordance with the obligations of a notary in Law Number 2 of 2014 concerning the Position of a Notary Article 16 Article 1 letter (f).

The Notary Position Act does not specifically regulate legal protection for notaries in the examination process related to false information, this is because the UUJN does not clearly regulate legal protection for notaries in criminal cases, not only that, UUJN also does not regulate criminal responsibility. a notary from the deed he has made based on data and information falsified by the parties, especially if the crime was committed by a notary staff.

Notaries are public officials who carry out the legal profession in providing services to the public.

b. Notary Authority

The authority of a Notary as a Public Official of the Republic of Indonesia is a state of law. The principle of the rule of law is to guarantee the existence of certainty, order and protection of the law which has the core of truth and justice in society. Notaries are public officials who are given some authority by the state and every action must be based on law. The position of a notary is the position of a state official or public official, based on the provisions of the UUJN, a public official is a person who carries out some public and state functions, especially in the field of civil law. 
International Journal of Social Science (IJSS)

Vol.1 No.3 October 2021, pp: 253-258

ISSN: 2798-3463 (Printed) | 2798-4079 (Online)

Notaries as public officials have the authority as regulated in Article 15 of the UUJN, namely as follows:

1. The notary has the authority to make an authentic deed regarding all actions, agreements, and stipulations required by the legislation and/or desired by the interested parties to be stated in an authentic deed, guarantees the certainty of the date of making the deed, keeps the deed, provides grosse, copies and quotations of the Deed, all of which are as long as the making of the Deed is not assigned or excluded to other officials or other people stipulated by law.

2. In addition to the authority as referred to in paragraph (1), a Notary is also authorized to:

a. Validate the signature and determine the certainty of the date of the letter under the hand by registering it in a special book.

b. Book a letter under the hand by registering in a special book

c. Make a copy of the original letter under the hand in the form of a copy containing the description as written and described in the letter in question.

d. Validate the compatibility of the photocopy with the original letter.

e. Provide legal counseling in connection with the making of the Deed

f. Make a deed related to land; or

g. Make a Minutes of Auction Deed.

(3) In addition to the authority as referred to in paragraph (1) and paragraph (2), a Notary has other powers as regulated in the laws and regulations.

c. Notary Staff

A notary requires a lot of preparation in making an authentic deed so that it requires staff who handle technical matters in administrative matters. Duties and Responsibilities of Notary Employees:

1)Becoming a Witness of Deed Ratification

Deed witnesses are needed during the ratification process to prove that the notary deed is authentic. Notary employees can serve as witnesses because one of the conditions is that the witness is known by the notary. Employees will listen to the reading of the contents of the notary deed and the affixing of signatures as a form of approval.

When the deed is read, the employee must really understand its contents in order to confirm that there is no mistake in the deed. Notary employees can also replace the notary to read the deed before the public if the notary has a sudden agenda or health problem.

2)Preparing for Deed

The duties of notary employees are limited to technical work. The aim is to speed up the manufacturing process, and make it easier for notaries to carry out their roles. Some of the technical matters that are the duties of notary employees in making the deed, among others:

a. Maintain communication with presenters.

b. Organize files to make them easier to retrieve when needed.

c. Make one minuta deed bundle per month. The maximum number of deed for one bundle is 50 . If the deed is more than that, then it must be made into several bundles.

d. Make a reportorium or a list of deeds.

e. Make a list of registered letters under the hand that have been approved.

f. Make a protest list book against securities received/not received.

g. Make a list of letters required by law.

h. Entering data in the form of the date of delivery of the will list in the reportorium every month.

i. Make a list of claper books for legalization.

j. Make a list of claper books for the presenters/parties.

3)Doing Document Archiving

The purpose of archiving is to store documents in a certain order neatly so that they are easy to find when needed. It is the duty of a notary employee to assist the notary in documentation because it is very important for office administration.

Important documents, also known as the Notary Protocol, are:

a) repertoire

b) Minutes of deed

c) Legalized list of deeds under the hand

d) Protest register

e) List of parties or presenters

f) Book of wills 
g)The register book that is important for a notary

d. Notary Criminal Liability

The concept of criminal responsibility is actually not only a matter of law, but also about moral values or general decency adopted by a society or groups in society, this is done so that criminal responsibility is achieved by fulfilling justice.

Criminal liability is a form of determining whether a suspect or defendant is responsible for a crime that has occurred. In other words, criminal liability is a form that determines whether a person is released or convicted.

If a notary commits a crime, then there is criminal responsibility. questionThe criminal responsibility of a notary is if in carrying out his position it is proven that he has committed a violation. The regulations do not specifically regulate criminal sanctions against notaries who falsify letters due to fraud and mistakes made by the appearers.

The responsibility of a Notary in the event of a falsification of a letter by the parties in making a Notary deed according to UUJN and the Amendment Act to the UUJN is that when a Notary in carrying out his position is proven to have committed a violation, the Notary is responsible in accordance with the actions he did, both responsibilities in terms of Administrative Law , Civil law.

2. Authentic Deed

a. Definition of Authentic Deed

According to Subekti, what is meant by a deed is "a writing that is intentionally made to be used as evidence about an event and signed". The deed has 2 (two) important functions, namely the formal function (formality causa) and the function of evidence (probationis causa). The formal function (formality causa) means that to complete or complete (not to be valid) a legal act must be made a deed. The function of evidence (probationis causa) is that the deed was remade intentionally for future proof, the written nature of an agreement in the form of a deed does not make the agreement valid, but so that it can be used as evidence in the future.

b. Requirements for a Notary Deed as an Authentic Deed

Authentic deeds are always considered true, unless proven otherwise in court. Evidence is regulated in Article 1866 of the Civil Code. Based on Article 1866 of the Civil Code, valid evidence or recognized by law consists of:

a. Written evidence.

b. Evidence with witnesses

c. conjectures

d. Confession

e. Oath.

c. The Power of Authentic Deed Proof

The power of proof of an authentic deed is a condition of assessing an authentic deed as evidence. In this case there are 3 (three) aspects that must be considered when the deed is made, these aspects are related to the evidentiary value, namely:

1)Outwardly (uitwendige bewijskracht)

2)Formal (formele bewijskracht)

3) Material (materialele bewijskracht)

3. Crime

a. Definition of Crime

A criminal act is a misconduct that is threatened by legislation, so a behavior that is generally prohibited by criminal threats.

b. Elements of a Crime

According to Moeljatno, a criminal act is an act that has elements and two related properties, elements that can be divided into two types, namely:

1) Subjective is related to the actor's self and includes everything that is contained in his heart.

2) Objectives are the elements that are attached to the perpetrator or which have something to do with his circumstances, namely in the circumstances in which the actions of the perpetrator must be carried out.

\section{RESEARCH METHODS}

The research method is descriptive analytical, which describes the problems and facts that occur based on positive legal norms, namely the laws related to this research. 
International Journal of Social Science (IJSS)

Vol.1 No.3 October 2021, pp: 253-258

ISSN: 2798-3463 (Printed) | 2798-4079 (Online)

DOI: https://doi.org/10.53625/ijss.v1i3.418

Method Approach with normative juridical that is using positive legal norms related toa crime committed by a notary staff who discloses the confidentiality of a notary's position.

Data analysis was carried out qualitatively, meaning without using numbers and statistical formulas.

\section{RESULTS AND ANALYSIS}

The notary in making the deed needs to keep all forms of information obtained while carrying out his office, which are regulated in the code of ethics and the notary position law. However, the notary in making the deed generally involves the administrative staff of the notary office.

The notary is required to be responsible for the deed he has made, sometimes the deed made before the notary contains false information, fraud and even untruth and is often subject to Articles 263, 264, and 266 in conjunction with Article 55 of the Criminal Code. The task of a notary is to enter data and information provided by the parties, in accordance with the obligations of a notary in Law Number 2 of 2014 concerning the Position of a Notary, article 16 article 1 letter (f).

The Law on the Office of Notaries does not specifically regulate legal protection for notaries in the examination process related to false information, when a notary is examined in a criminal case based on article 66 of the UUJN, it must obtain approval from the Constitutional Court.

During the examination process, the Honorary Council does not provide legal protection, this is because the UUJN does not clearly regulate legal protection for notaries in criminal cases, not only that, the UUJN also does not regulate the criminal responsibility of a notary from the deed he has made based on the data. and information falsified by the parties.

There is a Notary's responsibility in the event of a forgery of a letter carried out by the parties in making a Notary deed according to UUJN and the Amendment Act to UUJN is when a Notary in carrying out his position is proven to have committed a violation, the Notary is responsible according to the actions he has done, both responsibilities in terms of Administrative Law, Civil Law.

The role of the notary office administrative staff in maintaining the confidentiality of the deed according to the code of ethics and the oath of office of a notary. The role of the notary office administrative staff is part of the notary office organ that has a causal legal relationship that should act as a notary's obligation to maintain and keep the deed secret.

Act in accordance with the authority or instructions given by the notary. The legal consequences of notary office administrative staff who do not maintain the confidentiality of the deed, reprimand from the authorities, can be prosecuted in the form of civil charges, criminal charges and administrative sanctions.

The explanation of the article above is an example of a problem when a notary is proven guilty in carrying out his position, the notary is criminally responsible to the party who feels aggrieved by this. The legal consequences of notary office administrative staff who do not maintain the confidentiality of the deed. Notary office administrative staff who do not maintain the confidentiality of the deed can be charged with the provisions of Article 322 paragraph (1) of the Criminal Code, whoever deliberately discloses a secret that must be kept because of his position or disbursement, both now and in the past, is threatened with imprisonment. imprisonment for a maximum of nine months or a maximum fine of nine thousand rupiahs.

Discussion related to Article 322, every person who discloses a secret that must be kept because of his position or disbursement is threatened with a maximum imprisonment of nine months or a maximum fine of nine thousand rupiahs. So the administrative staff of the notary office will be threatened with a criminal if they cannot keep the secret of the deed made by the parties before a notary. Criminal responsibility is imposed on those who commit the act.

Before being appointed, the notary has promised in his oath of office to keep the contents of the deed and all information obtained in carrying out his office confidential. The position of a notary is a very noble profession as a notary so it is required to maintain the confidentiality of the contents of the deed, regulated in a notary professional code of ethics in the code of ethics of the Indonesian Notary Association (INI) and the Notary Position Act.

The authority of a notary in carrying out its main duties is: a notary has the authority to make an authentic deed regarding all acts of the agreement, and the stipulations required by laws and regulations and/or that are desired by the interested parties to be stated in an authentic deed, guarantee the certainty of the date of making the deed, save the deed, provide processing of the deed, copies and quotations of the deed, all of which are as long as the making of the deed is not assigned or excluded to other officials or other persons stipulated by law.

Carrying out this authority, the notary requires assistance from other people, who assists the notary in carrying out his position. Based on the theory of public office organs, organ as a legal term is a tool of equipment, meaning that it is a person or assembly consisting of people who based on the law or articles of association are authorized to express and analyze the will of a legal entity. By means of these equipment, legal entities take part in legal traffic. 


\section{CONCLUSION}

1. The role of the notary office administrative staff in maintaining the confidentiality of the deed according to the code of ethics and the oath of office of the notary. The role of the notary office administrative staff is part of the notary office organ that has a causal legal relationship that should act as a notary obligation to maintain and keep the deed secret.

2. Legal consequences The administrative staff of a notary office who does not maintain the confidentiality of the deed can be charged with the provisions of Article 322 paragraph (1) of the Criminal Code, whoever deliberately discloses a secret that must be kept because of his position or disbursement, both now and in the past, is threatened with a maximum imprisonment of nine months or a maximum fine of nine thousand rupiahs.

Suggestion

1. It is recommended that Government Regulation Number 24 of 2016 concerning Regulations on the Position of Land Deed Making Officials and Law Number 2 of 2014 regulate provisions regarding criminal sanctions for Notaries/PPAT and their staff who violate the prohibitions or obligations of Notaries/PPAT.

2. Legal arrangements in Indonesia must be confirmed and judges should consider everything that must be considered. It is better if the punishment related to the profession should be given a heavier penalty because the notary/PPAT has understood his responsibilities and actions in carrying out the profession.

\section{REFERENCES}

[1] Abdul Ghofur Anshori, Indonesian Notary Institution; legal and ethical perspective,

[2] First Printing, Yogyakarta, UII Press, 2009.

[3] Adami Chazawi, The Crime Against Counterfeiting. PT. Raja Grafindo Persada, Jakarta, 2012.

[4] Anke Dwi Saputro, The Identity of Indonesian Notaries Before, Now, and in the Future, Gramedia Pustaka, Jakarta, 2016.

[5] GHS Lumban Tobing, Notary Position Regulations, Jakarta, Erlangga, 2003.

[6] Habib Adjie, Notary Law in Indonesia Thematic Interpretation of Law NO. 30 of 2004 concerning the Position of Notary, Rafika Aditama, Bandung, 2016.

[7] Habib Adjie, World Overview of Notaries and PPAT Indonesia (Collection of Writings), First Printing, Bandung, CV. Mandar Maju, 2009.

[8] Civil and Administrative Sanctions Against Notaries as Public Officials, Bandung, Refika Aditama, 2009.

[9] Mahrus Hanafi, Criminal Accountability System, First Printing, Jakarta, Rajawali Press, 2015.

[10] Moeljatno. Principles of Criminal Law. Rineka Cipta. Jakarta, 2015.

[11] Munir Fuady, Unlawful Acts, Contemporary Approach, Cet.2, Citra Adytia, Bandung, 2015.

[12] Subekti, Law of Evidence, PT. Pradnya Paramitha, Jakarta, 2015.

[13] Sudikno Mertokusumo, Introduction to Law, Liberty, Yogyakarta, 2015.

[14] Tri Andrisman. Criminal law. Lampung University. Bandar Lampung. 2017. 